\title{
Commercial Speech in User-Generated Media: An Analysis of the FTC's Revised Guides Concerning Use of Endorsements and Testimonials in Advertising*
}

\section{INTRODUCTION}

The invention of the Internet has ushered in a new age for consumers. Often, consumers first look to the Internet when evaluating a product. With product-review websites, blogs, Facebook, and Twitter, consumers can learn everything about a product—from how it works to the cheapest place to buy it-all from the comfort of their own homes. But consumers are no longer just observing. "[I]ndividual citizens of limited means can speak to a worldwide audience on issues of concern to them." 1 The Internet allows consumers to be both the speaker and the audience. $^{2}$ Of course, where consumers go, advertisers surely follow. And where advertisers go, the Federal Trade Commission (FTC) follows as well.

Advertisers quickly adapt to new opportunities for advertising in consumer-driven social media, and the FTC strives to keep up with the changes. In October 2009, the FTC published a revised version of the Guides Concerning Use of Endorsements and Testimonials in Advertising (Guides), which interpret endorsement- and testimonialadvertising law. ${ }^{3}$ For the first time, the Guides incorporated examples of how to apply the laws of endorsement and testimonial advertising to online user-generated media. ${ }^{4}$ The FTC extended its reach beyond regulating traditional advertisements by promulgating rules to regulate nontraditional consumer endorsements as well. ${ }^{5}$ While the Guides have

* Jessica Shannon. J.D. candidate 2012, University of Kansas School of Law.

1. Robert Kline, Freedom of Speech on the Electronic Village Green: Applying the First Amendment Lessons of Cable Television to the Internet, 6 CORNELL J.L. \& PUB. POL'Y 23, 46 (1996) (quoting ACLU v. Reno, 929 F. Supp. 824, 881 (E.D. Pa. 1996) (internal quotation marks omitted), aff'd 521 U.S. 844 (1997)).

2. See id. ("[T]hese [low] barriers to entry are identical for both speakers and listeners." (quoting Reno, 929 F. Supp. at 877) (internal quotation marks omitted)).

3. 16 C.F.R. $\S \S 255.0-255.5$ (2011).

4. See id.

5. See id. § 255.0. The Guides state that: 
not changed any legal principles, they attempt to apply old rules fashioned for traditional media to new technologies. ${ }^{6}$

As the FTC has tried to keep up with changing practices, it has increased the risk consumer-endorsers face by complicating the application of the laws. The FTC's purpose is to protect consumers, and the current Guides fail to achieve that purpose. The 2009 revisions of the Guides go beyond the scope of the FTC's authority to regulate commercial speech and provide an inadequate explanation of the law concerning endorsement and testimonial advertising in online usergenerated media. The Guides must be further refined to avoid a chilling effect-dissuading consumers from sharing their opinions-caused by ambiguous definitions regarding endorsements in user-generated media.

This Comment discusses the deficiencies of the Guides' application to user-generated media and proposes possible solutions to make the examples more specific to resolve the current ambiguities. Part II details the 2009 revisions and current application of the laws of endorsement and testimonial advertising to online media. Part III begins by arguing that the current Guides are overbroad and regulate noncommercial speech in a way that chills legitimate free speech on the Internet. Part III recognizes arguments in support of the current Guides and discusses policy reasons for further defining the Guides. Part III closes by suggesting courses of action the FTC should take to remedy the effect of the Guides on user-generated media.

\section{BACKGROUND}

The 2009 revision of the Guides marked the first time that the FTC incorporated examples of user-generated content from online sources,

[A]n endorsement means any advertising message (including verbal statements, demonstrations, or depictions of the name, signature, likeness or other identifying personal characteristics of an individual or the name or seal of an organization) that consumers are likely to believe reflects the opinions, beliefs, findings, or experiences of a party other than the sponsoring advertiser, even if the views expressed by that party are identical to those of the sponsoring advertiser. Id. § 255.0(b).

6. See Press Release, Fed. Trade Comm'n, FTC Publishes Final Guides Governing Endorsements, Testimonials (Oct. 5, 2009), available at http://www.ftc.gov/opa/2009/10/ endortest.shtm [hereinafter FTC Press Release] (explaining that the Guides provide "examples to illustrate the long standing principle that 'material connections'... between advertisers and endorsers ... must be disclosed" and citing as such examples advertisements used in blogs and by celebrities). 
such as blogs, into the Guides." "In a recent Deloitte survey of 2,000 Internet users ranging in age from thirteen to seventy-five, close to half said they had created content-blogs, music, photos, videos, and Web sites-for others to view online."8 These new media create a novel platform for consumers to disseminate their opinions to the public, which sometimes include sponsored endorsements. The Guides provide a start for regulating online consumer endorsements, but the Guides' definitions and examples also leave significant ambiguity in this area of law.

\section{A. Revisions Addressing Disclosure of Material Connections}

The FTC focused on disclosing material connections between advertisers and endorsers when it incorporated user-generated media into the Guides. ${ }^{9}$ The Guides simply require an endorser to fully disclose any material connections that exist between the endorser and advertiser. ${ }^{10}$ According to the Guides, a material connection exists if such a connection "might materially affect the weight or credibility of the endorsement" or "is not reasonably expected by the audience." 11 The remainder of $\S 255.5$ of the Guides consists of examples depicting scenarios in which the FTC expects disclosure. ${ }^{12}$ The FTC attempts to explain the application of the Guides to user-generated media through these examples by demonstrating when disclosure of material connections is necessary. ${ }^{13}$

The FTC intended to define and illustrate what constitutes an endorsement in user-generated, word-of-mouth advertising by incorporating examples seven, eight, and nine in $\S 255.5$ of the Guides. ${ }^{14}$ Example seven in $\S 255.5$ provides a clear case of endorsement where a blogger, prominent in the video game arena, receives free products from

7. See 16 C.F.R. $\S \S 255.0-255.6$. Other revisions to the Guides not pertinent to the analysis in this Comment include the clarification of the duties of celebrity endorsers and the elimination of the safe-harbor rule allowing the statement "results not typical" to accompany advertisements claiming atypical results. Id. §§ 255.1(b) \& ex. 4, 255.2(b) \& n.105.

8. Edward Lee, Warming Up to User-Generated Content, 2008 U. ILL. L. REV. 1459, 1500 (citing Can Your Cat Play Piano?, LATIMEs.com (Jan. 14, 2008), http://articles.latimes.com/2008/ jan/14/opinion/ed-content14).

9. FTC Press Release, supra note 6.

10. 16 C.F.R. § 255.5 .

11. Id.

12. See id. § 255.5 exs. 1-9.

13. Id. $\S 255.5$ ("Additional guidance, including guidance concerning endorsements made through other media, is provided by the examples ....”).

14. FTC Press Release, supra note 6. 
a video game manufacturer as a matter of custom. ${ }^{15}$ In this specific instance, the blogger receives a free video game system and writes a favorable review of the product. ${ }^{16}$ This example clearly conveys the idea that consumer-speakers who receive free products of significant value through ongoing relationships with manufacturers qualify as endorsers. ${ }^{17}$ It leaves to the imagination, however, whether receipt of a single product of moderate value-or even a series of nominally valued products—falls within this definition.

Example eight in $\S 255.5$ addresses a situation in which an employee of a company promotes his employer's products on relevant online discussion boards without disclosing his employment relationship. ${ }^{18}$ Example nine, the final example under $\S 255.5$ that addresses material connections, describes a situation in which a member of a marketing street team receives points, which can be exchanged for prizes, each time the member discusses a particular advertiser's products with his friends. ${ }^{19}$ A street team is a viral marketing tool in which the advertiser or manufacturer hires laypersons to speak with consumers about the advertiser's product or service. ${ }^{20}$ In some situations, members of a street team are not compensated, but merely want to promote a product to which they are loyal. ${ }^{21}$ While this example does not specifically address online media, its application to social networking sites such as Facebook or Twitter is inferential. A member of an online street team might share his views or experiences through Facebook or Twitter updates or by posting on Internet message boards. ${ }^{22}$

Another portion of the Guides relating to user-generated content on new media is example eight of $\S 255.0 .^{23}$ This section introduces the Guides, provides a statement of their authority, defines endorsement, and provides illustrative examples. ${ }^{24}$ The section states that "[w] hether a particular endorsement or testimonial is deceptive will depend on the

15. 16 C.F.R. § 255.5 ex. 7.

16. Id.

17. See id. (instructing that the favorable review by the blogger constitutes an endorsement).

18. Id. § 255.5 ex. 8.

19. Id. § 255.5 ex. 9 (internal quotation marks omitted).

20. Wayne Friedman, Street Marketing Hits the Internet, AdVERTISING AgE, May 1, 2000, at 32, available at http://adage.com/article?article_id=58536.

21. See id. (explaining that many street team members do not want free offers or discounts, but instead want to be involved in promoting singers, actors, and other artists).

22. See id. (describing the emails and internet postings that street team members use).

23. 16 C.F.R. § 255.0 ex. 8.

24. Id. § 255.0 \& exs. $1-8$. 
specific factual circumstances of the advertisement at issue.”25 Example eight discusses different scenarios in which a woman tries a new brand of dog food and discusses it on her blog. ${ }^{26}$ The example demonstrates that the method by which the blogger obtained the product determines whether she qualifies as an endorser under the revised Guides. ${ }^{27}$ The receipt of free products can trigger disclosure requirements depending on the surrounding circumstances. ${ }^{28}$ The exact circumstances that create a material connection, however, are unclear.

\section{B. Ambiguities in the Revised Guides}

The FTC adopted the revisions discussed above in 2009, and these revisions represent the current Guides. ${ }^{29}$ Ambiguities still remain. In a statement made at the American Conference Institute's Regulatory Summit for Advertisers and Marketers, FTC Commissioner, J. Thomas Rosch, discussed some of the issues with the proposed Guides released for comment in 2008:

Suppose a diaper manufacturer sends a year's supply of free diapers to a mom who has an online blog about baby products. Would readers of the blog reasonably expect this connection? Would knowledge of this freebie materially affect the weight they would give to the blogger's touting of the diapers? What did the manufacturer expect from the blogger when it provided the free diapers? Imagine a scenario where the manufacturer also provided free diapers to other mothers. What if that mother tells the parent next door about how great the diapers are over the clothesline? Is a disclosure necessary in that context? How do we differentiate that latter situation from the one where another recipient of free diapers instead "blogs" the same message? Is it just the breadth of the dissemination that matters? Is it the intent of the manufacturer? Or does liability turn upon what the recipient of the "message" expects? These are some of the issues that ... staff will be grappling with as they review the comments submitted and finalize the Guides. $^{30}$

25. Id. § 255.0(a).

26. Id. § 255.0 ex. 8 .

27. See id. (determining that, under the assumptions listed, certain consumer actions may be considered endorsements).

28. Id. § 255.5 ex. 7.

29. Id. §§ 255.0-255.5.

30. J. Thomas Rosch, Comm'r, Fed. Trade Comm'n, Address at the American Conference Institute's Regulatory Summit for Advertisers and Marketers (June 25, 2009). 
Despite the Commissioner's assertion that the FTC would likely address the issues of differentiation, these issues remain unresolved by the current Guides. ${ }^{31}$

While the examples contained in the Guides fail to create a clear depiction of the Guides' application to user-generated media, the FTC released the following statement on its website: "The revised Guides specify that while decisions will be reached on a case-by-case basis, the post of a blogger who receives cash or in-kind payment to review a product is considered an endorsement." 32 In the publication of the final rule, the FTC stated:

[T] he fundamental question is whether, viewed objectively, the relationship between the advertiser and the speaker is such that the speaker's statement can be considered "sponsored" by the advertiser and therefore an "advertising message." In other words, in disseminating positive statements about a product or service, is the speaker: (1) acting solely independently, in which case there is no endorsement, or (2) acting on behalf of the advertiser or its agent, such that the speaker's statement is an "endorsement" that is part of an overall marketing campaign ? $^{33}$

Factors to be considered in determining whether a statement is sponsored include: the compensation paid by the advertiser; the receipt of free products; the agreements between the advertiser and speaker; the length of the relationship between the advertiser and speaker; the previous receipt of products from the same or similar advertisers; the value of the items received; and the likelihood of receiving future products. $^{34}$ In a question-and-answer section of its website, the FTC emphasized that receiving rewards from a manufacturer with the consumer's understanding that the consumer will promote the advertiser's product is a connection covered by the Guides. ${ }^{35}$ Further,

31. For a discussion of ambiguous provisions in the Guides, see Jason Goldstein, Note, How New FTC Guidelines on Endorsement and Testimonials Will Affect Traditional and New Media, 28 CARDOZO ARTS \& ENT. L.J. 609, 618-23 (2011) (questioning application of the new Guides to celebrity, third party, and blogger liability).

32. FTC Press Release, supra note 6.

33. Guides Concerning the Use of Endorsements and Testimonials in Advertising, 74 Fed. Reg. 53,124, 53,126 (Oct. 15, 2009) (to be codified at 16 C.F.R. pt. 255).

34. Id. See also 16 C.F.R. $\S 255.5$ (providing examples of sponsorship and its relation to material participation).

35. Fed. Trade Comm'n, The FTC's Revised Endorsement Guides: What People Are AsKING 3 (2010), available at http://business.ftc.gov/documents/bus71-ftcs-revised-endorsementguideswhat-people-are-asking.pdf. 
receiving items of nominal value may constitute a material connection. ${ }^{36}$ The FTC further states, "[w]hile getting one item [that is] not very valuable for free may not affect the credibility of what [a consumer] say[s], sometimes continually getting free stuff from an advertiser or multiple advertisers is enough to suggest an expectation of future benefits from positive reviews., 37

\section{History of the Guides}

Before 2009, the FTC most recently revised the Guides in $1980 .^{38}$ The FTC tailored the previous Guides to apply in traditional modes of advertising such as print, radio, and television. ${ }^{39}$ The FTC first created the Guides Concerning Use of Endorsements and Testimonials in Advertising in 1975. ${ }^{40}$ The Guides are administrative interpretations of the Federal Trade Commission Act (FTCA) that assist advertisers in conforming to the law. ${ }^{41}$ The FTC's authority to administer the Guides originates in the FTCA, which provides that " $[\mathrm{t}]$ he Commission is hereby empowered and directed to prevent persons, partnerships, or corporations ... from using unfair methods of competition in or affecting commerce and unfair or deceptive acts or practices in or affecting commerce." ${ }^{42}$ The Guides provide substantive definitions, interpretations, and examples that describe the FTC's understanding of unfair or deceptive acts, which violate the FTCA. ${ }^{43}$ While the Guides are not binding law, breach of their recommendations can result in enforcement action by the FTC pursuant to the FTCA. ${ }^{44}$ "The Guides set forth the general principles that the Commission will use in evaluating

36. Id.

37. Id.

38. FTC Press Release, supra note 6.

39. See Prepared Statement of the Fed. Trade Comm'n on Adver. Trends and Consumer Prot.: Hearing Before the Subcomm. on Consumer Prot., Prod. Safety, and Ins. of the Comm. on Commerce, Sci., and Transp., 111th Cong. 1-2, 9 (2009) (statement of David Vladeck, Dir., Bureau of Consumer Protection). "The 1980 Guides were adopted in a world that was quite different from the one in which advertisers and marketers promote their goods and services today." Id.

40. Guides Concerning Use of Endorsements and Testimonials in Advertising, 40 Fed. Reg. 22,127 (May 21, 1975) (to be codified at 16 C.F.R. pt. 255).

41. 16 C.F.R. § 255.0(a) (2011).

42. 15 U.S.C. $\S 45(a)(2)(2006)$.

43. See 16 C.F.R. $\S \S 255.0-255.5$.

44. Id. §255.0(a) (noting that "[p]ractices inconsistent with [the] Guides may result in corrective action”). 
endorsements and testimonials ...."45 While the FTCA grants to the FTC broad authority to regulate unfair or deceptive acts, the First Amendment and the commercial-speech doctrine limit the FTC's regulation of commercial speech. ${ }^{46}$

\section{Other Sources of Regulation}

While other sources of deceptive-advertising regulation exist, ${ }^{47}$ the FTC's interpretations influence most other forms of regulation. ${ }^{48}$ State attorneys general may also monitor and regulate online user-generated advertising pursuant to state laws that prohibit deceptive trade practices. $^{49}$ Most states have adopted unfair and deceptive acts and practices statutes modeled after the FTCA, and these states generally rely on the FTC Guides for interpretations and definitions. ${ }^{50}$ Many state statutes contain clauses that explicitly require the statute to be construed with reference to FTC interpretations. ${ }^{51}$

Although this is the first time the FTC has published regulations controlling endorsements and testimonials in online user-generated media, industry groups and websites have previously required selfregulation by advertisers. ${ }^{52}$ Facebook's Statement of Rights and

45. Id. § 255.0(a).

46. See Cent. Hudson Gas \& Elec. Corp. v. Public Serv. Comm’n, 447 U.S. 557, 566 (1980) ("In commercial speech cases ... we must determine whether the expression is protected by the First Amendment.”); Ellen P. Goodman, Peer Promotions and False Advertising Law, 58 S.C. L. ReV. 683, 696-97 (2007).

47. See, e.g., 15 U.S.C. §§ 1051-1141 (governing false advertising claims by advertisers alleging injury to a trademark); see also Colo. REv. STAT. ANN. §§ 6-1-101 to -115 (West 2002 \& Supp. 2010) (prohibiting deceptive trade practices); KAN. STAT. ANN. §§ 50-623 to -643 (2005 \& Supp. 2010) (same); NEB. REV. STAT. §§ 87-301 to -306 (2009 \& Supp. 2010) (same); OKLA. STAT. ANN. tit. 78, §§ 51-55 (West 2002 \& Supp. 2010) (same).

48. Jessica Godell, Comment, Consumer-Generated Media and Advertising-Are They One and the Same? An Analysis of the Amended FTC Guides Concerning the Use of Endorsements and Testimonials in Advertising, 10 J. MARSHALl REV. INTELL. PROP. L. 206, 209 (2010) (“A number of courts that have dealt with false advertising litigation, as well as the administrative agencies responsible for implementing false advertising legislation, recognize FTC guides as pertinent to their interpretations.").

49. See Jeff Sovern, Private Actions Under the Deceptive Trade Practices Acts: Reconsidering the FTC Act as Rule Model, 52 Оніо Sт. L.J. 437, 446-52 (1991) (discussing enforcement of "Little FTC Acts”).

50. Consuelo Lauda Kertz \& Roobina Ohanian, Recent Trends in the Law of Endorsement Advertising: Infomercials, Celebrity Endorsers and Nontraditional Defendants in Deceptive Advertising Cases, 19 HOFSTRA L. REv. 603, 631 (1991).

51. Id.

52. See, e.g., The Ethics Code, Word OF Mouth MARKETING Ass'N, http://womma.org/ethics/ ethicscode.pdf (last visited Nov. 5, 2011) [hereinafter The Ethics Code, WOMMA] (describing the 
Responsibilities requires users to agree not to use a personal profile for commercial gain, such as by selling a status to an advertiser. ${ }^{53}$ A status is a message posted by a Facebook user through his or her profile that is published for other Facebook users-also called Facebook "friends"-to read. Therefore, selling a status likely would involve a user agreeing to post certain messages - often endorsements or testimonials - in exchange for payment from an advertiser or product manufacturer. Although most lay people probably do not realize that they agree to this policy, the policy regulated consumer endorsement before the FTC issued the revised Guides. The difference between the Facebook policy and the Guides is merely definitional. ${ }^{54}$ The Facebook policy regulates any endorsement made for "commercial gain," but never defines what constitutes a commercial gain. ${ }^{55}$ The Guides attempt to regulate a broader category of statements by requiring only a material connectionnot commercial gain-between a manufacturer and consumer-endorser. ${ }^{56}$

In addition, the Word of Mouth Marketing Association (WOMMA), a trade association for advertisers or marketers who employ word-ofmouth marketing, also requires that its members comply with ethical standards similar to those found in the FTC Guides. ${ }^{57}$ Specifically, members must "require their representatives involved in a word of mouth initiative to disclose the material aspects of their commercial relationship with a marketer, including the specific type of any remuneration or consideration received." 58

Although a similar ethics code existed before the adoption of the 2009 Guides, the WOMMA ethics code now provides that "[t]he fulcrum of the Codes and Standards is the Guides Concerning Use of Endorsements and Testimonials in Advertising promulgated by the Federal Trade Commission."59 As with the state statutes prohibiting

Word of Mouth Marketing Association and its dedication "to engaging in practices and policies that promote an environment of trust between the consumer and marketer"); Statement of Rights and Responsibilities, FACEBOOK, http://www.facebook.com/terms.php?ref=pf (last visited Oct. 14, 2011) [hereinafter Statement of Rights, FACEBOOK] (containing "[s]pecial [p]rovisions [a]pplicable to [a]dvertisers").

53. Statement of Rights, FACEBOOK, supra note 52.

54. Compare id. (defining prohibited acts in terms of their potential for commercial gain), with 16 C.F.R. § 255.5 (2011) (regulating advertisements and endorsements for which there exists a material connection between the endorser and seller).

55. See Statement of Rights, FAСЕВOOK, supra note 52.

56. 16 C.F.R. § 255.5 .

57. See The Ethics Code, WOMMA, supra note 52.

58. Id.

59. Id. 
unfair and deceptive acts and practices, the industry guidelines depend on clear, unambiguous FTC regulations to govern word-of-mouth marketing in accordance with ethical industry practices. The WOMMA code, however, only applies to WOMMA members who are individuals or business entities specifically involved in the marketing of a product or service. $^{60}$ Thus, unlike the Guides, the WOMMA code does not risk chilling legitimate free speech of lay consumers.

\section{E. The Revision Process}

Prior to releasing the 2009 Guides, the FTC sought input on the impact, benefits, and regulatory effect of the Guides in $2007,{ }^{61}$ and it released proposed revisions for public comment in $2008 .{ }^{62}$ The bulk of the Guides' application to user-generated media is contained in examples seven, eight, and nine, and in $\S 255.5,{ }^{63}$ which were not mentioned or proposed in the 2007 Request for Public Comment. ${ }^{64}$ The FTC added the examples to the 2008 proposal $^{65}$ and adopted them as part of the revised Guides in 2009. ${ }^{6}$ The Guides' examples covering user-generated media, which were developed and released for public comment in $2008,{ }^{67}$ had less opportunity for public comment as compared to other adopted revisions, which were included in a Request for Public Comment in 2007. ${ }^{68}$ The FTC adopted some of the proposed revisions from both the

\footnotetext{
60. Id.

61. Request for Public Comment, 72 Fed. Reg. 2214 (Jan. 18, 2007).

62. Notice of Proposed Revisions to the Guides, 73 Fed. Reg. 72,374 (Nov. 28, 2008).

63. 16 C.F.R. § 255.5 (2011); see also supra notes 14-28 and accompanying text.

64. See Request for Public Comment, 72 Fed. Reg. at 2214.

65. Public Comment from Edward F. Glynn, Jr. on behalf of the Am. Ass'n of Adver. Agencies, Am. Adver. Fed'n, Council for Responsible Nutrition, Direct Mktg. Ass'n, Direct Selling Ass'n, Elec. Retailing Ass'n, Interactive Adver. Bureau, Promotion Mktg. Ass'n, and U.S. Chamber of Commerce, to Donald S. Clark, Sec'y, Fed. Trade Comm'n 5 (Mar. 2, 2009), available at http://www.ftc.gov/os/comments/endorsementguides2/539124-00013.pdf [hereinafter Glynn Public Comment].

66. See Guides Concerning the Use of Endorsements and Testimonials in Advertising, 74 Fed. Reg. 53,124 (Oct. 15, 2009) (to be codified at 16 C.F.R. pt. 255) (including examples seven, eight, and nine).

67. Notice of Proposed Revisions to the Guides, 73 Fed. Reg. at 72,374; see also Glynn Public Comment, supra note 65, at 5.

68. The 2007 Request for Public Comment sought feedback on possible changes both to the safe-harbor rule, which would allow disclaimers of typicality in testimonials, and the disclosure of material connections for celebrity endorsers. Request for Public Comment, 72 Fed. Reg. at 221617. The 2007 Request for Public Comment did not detail the exact revisions that the FTC adopted in 2009. See generally id. at 2214-17 (requesting "public comment on the overall costs, benefits, and regulatory and economic impact of [the] Guides," but not detailing any particular revisions). The
} 
2007 and 2008 releases as part of the 2009 revised Guides. ${ }^{69}$ Thus, the revisions involving user-generated media contained in the 2008 release were available for debate and revision for half as long as the revisions discussed in the 2007 release. $^{70}$

In addition to the provisions pertaining to new media, the Guides also incorporated a clause providing that both the advertiser and the endorser could incur liability for statements made during the course of the endorsement. ${ }^{71}$ The 2009 revisions to the Guides also clearly impose liability on both advertisers and endorsers for statements made in an endorsement or for failure to disclose material connections. ${ }^{72}$ The FTC first developed joint endorser and advertiser liability through caselaw, and the revised Guides explicitly include it in the regulations for the first time. $^{73}$ Given the current ambiguities in the Guides concerning disclosure of material connections in consumer-generated media and joint liability, the Guides increase consumer risk rather than consumer protection. Such a result directly conflicts with the principal aim of the Guides and the purpose of the FTC.

\section{ANALYSIS}

Although the 2009 revisions illustrate the FTC's progress in adapting the laws of testimonial and endorsement advertising to user-generated media, the Guides' current definitions and examples create ambiguity. Because of the ambiguity, the Guides are overbroad and chill commercial speech. First, this section will address the Guides' regulation of noncommercial speech and examine how regulation of both commercial and noncommercial speech subjects the Guides to the overbreadth doctrine. Second, this section will explore how the Guides

FTC outlined the safe-harbor revision and the material-connection revision in the 2008 release of proposed revisions, which also included revisions relating to online consumer-endorser content. See Notice of Proposed Revisions to the Guides, 73 Fed. Reg. at 72,379-90.

69. See Guides Concerning the Use of Endorsements and Testimonials in Advertising, 74 Fed. Reg. at 53,124 (indicating that "[t]he revised Guides include additional changes not incorporated in the proposed revisions published for public comment in November 2008”).

70. Compare Request for Public Comment, 72 Fed. Reg. at 2214 (requesting public comment regarding the safe-harbor rule and celebrity disclosure of material connections in 2007), with Notice of Proposed Revisions to the Guides, 73 Fed. Reg. at 72,374 (proposing revisions to the safe-harbor rule and the material-connections rule in 2008, as well as incorporating examples applicable to online media not previously discussed).

71. 16 C.F.R. § 255.1(d) (2011).

72. Id.

73. FTC Press Release, supra note 6. 
create a chilling effect on consumer speech and analyze why the Guides are invalid under the overbreadth doctrine. Finally, this section will discuss how the FTC may revise the Guides to avoid chilling legitimate speech and defeat a facial challenge under the overbreadth doctrine.

\section{A. The Guides Cover Noncommercial Speech that the FTC Lacks Authority to Regulate}

As stated above, the U.S. Constitution and the FTCA limit the FTC's authority to regulate commercial speech. ${ }^{74}$ An analysis of the development of the commercial-speech doctrine demonstrates that the FTC overreached its authority by promulgating the revised Guides. Both the First Amendment and the Due Process Clause provide for facial challenges to an overbroad regulation of protected speech. ${ }^{75}$ Any regulation of unprotected speech is unconstitutionally overbroad if the regulation also encompasses protected speech. ${ }^{76}$ Thus, whether the Guides are an overbroad regulation of protected speech requires courts to first determine whether any of the speech discussed in the Guides falls short of a commercial-speech designation and makes regulation of such speech suspect.

\section{Defining Commercial Speech}

Commercial speech is "expression related solely to the economic interests of the speaker and its audience."77 Commercial speech also includes speech that does "no more than propose a commercial transaction."78 The Supreme Court has held that the First Amendment offers less protection for commercial speech. Specifically, the Court

74. See Cent. Hudson Gas \& Elec. Corp. v. Pub. Serv. Comm’n, 447 U.S. 557, 566 (1980) (finding that the First Amendment places restrictions on the regulation of free speech); Goodman, supra note 46 , at 696-97.

75. Ashcroft v. Free Speech Coal., 535 U.S. 234, 244 (2002) (providing for facial challenges under the First Amendment); Vill. of Hoffman Estates v. Flipside, Hoffman Estates, Inc., 455 U.S. 489, 497 (1982) (providing for facial challenges under the Due Process Clause).

76. Free Speech Coal., 535 U.S. at 255 ("The overbreadth doctrine prohibits the Government from banning unprotected speech if a substantial amount of protected speech is prohibited or chilled in the process.").

77. Cent. Hudson, 447 U.S. at 561 (citing Friedman v. Rogers, 440 U.S. 1, 11 (1979); Bates v. State Bar of Ariz., 433 U.S. 350, 363-64 (1977); Va. State Bd. of Pharmacy v. Va. Citizens Consumer Council, Inc., 425 U.S. 748, 762 (1976)).

78. Va. State Bd. of Pharmacy, 425 U.S. at 762 (internal quotation marks omitted) (quoting Pittsburgh Press Co. v. Pittsburgh Comm'n on Human Relations, 413 U.S. 376, 385 (1973)). 
"[has] afforded commercial speech a limited measure of protection, commensurate with its subordinate position in the scale of First Amendment values, while allowing modes of regulation that might be impermissible in the realm of noncommercial expression., ${ }^{\text {,9 }}$ The Guides' ambiguity leads to regulation of some forms of noncommercial speech.

"[S]peech does not lose its First Amendment protection” merely because a party pays money to disseminate it. ${ }^{80}$ Thus, receipt of products of nominal value prior to a consumer's endorsement does not necessarily place endorsing speech in the realm of FTC-regulated commercial speech. In Bolger v. Youngs Drug Products Corp., the Supreme Court set forth factors to consider when classifying nontraditional forms of commercial speech. ${ }^{81}$ The factors include: (1) the speech's designation as advertising; (2) the content's reference to specific products; and (3) the economic motivation of the speaker. ${ }^{82}$ After applying the factors to determine whether different pamphlets that advertised contraception and provided information about disease and family planning were commercial speech, the Court stated:

The mere fact that these pamphlets are conceded to be advertisements clearly does not compel the conclusion that they are commercial speech. Similarly, the reference to a specific product does not by itself render the pamphlets commercial speech. Finally, the fact that Youngs has an economic motivation for mailing the pamphlets would clearly be insufficient by itself to turn the materials into commercial speech. ${ }^{83}$

The Bolger Court found that while the existence of each of the factors on its own was insufficient to establish the speech as commercial, the combination of all the factors provided "strong support" for such a characterization. $^{84}$ Other cases, however, have classified speech as commercial based on the economic motivation. In Central Hudson Gas \& Electric Corp. v. Public Service Commission of New York, the Supreme Court defined commercial speech as "expression related solely

79. Ohralik v. Ohio State Bar Ass’n., 436 U.S. 447, 456 (1978).

80. Va. State Bd. of Pharmacy, 425 U.S. at 761 (citing Buckley v. Valeo, 424 U.S. 1, 35-39 (1976); Pittsburgh Press, 413 U.S. at 384; N.Y. Times Co. v. Sullivan, 376 U.S. 254, 266 (1964)).

81. 463 U.S. 60, 65-67 (1983).

82. See id. (finding that the combination of the three factors leads to the conclusion that the mailing constitutes commercial speech).

83. Id. at 66-67 (footnote omitted) (citations omitted).

84. Id. at 67-68. 
to the economic interests of the speaker and its audience." 85 Thus, the most dispositive of the Bolger factors appears to be the economic motivation of the speaker.

\section{a. Economic Motivation}

The FTC seemingly attempts to regulate consumer-endorser speech in terms of economic motivation when it defines material connections. ${ }^{86}$ The attempt, however, falls short of differentiating between commercial and noncommercial speech. Section 255.5 of the Guides, which requires disclosure of material connections to advertisers, defines material connection-by example-in terms of the economic motivation of the speaker. $^{87}$ For example, each illustrative example contained in $\S 255.5$ pertaining to user-generated content, with the exception of example eight, includes the receipt of significant economic value-through either payment or free products-by the consumer-endorser. ${ }^{88}$ An examination of the caselaw defining economic motivation in commercial speech, however, will establish that the FTC's inclusion of endorsers receiving no payment—but merely free product samples—falls outside the scope of commercial speech.

Commentators have recognized that many federal circuit courts agree it is not necessarily true that whenever the motivation for speech is economic, the speech is commercial. ${ }^{89}$ The inquiry is more factintensive. One example where a court found that the economic motivation was insufficient to support a finding of commercial speech involved the owner of a financial magazine who published his own statements in his magazine and later included the statements in a promotional mailing that advertised the magazine. ${ }^{90}$ The statements

85. 447 U.S. 557, 561 (1980) (citing Friedman v. Rogers, 440 U.S. 1, 11 (1979); Bates v. State Bar of Ariz., 433 U.S. 350, 363-64 (1977); Va. State Bd. of Pharmacy, 425 U.S. at 762).

86. See 16 C.F.R. § 255.5 (2011) (“[T]he advertiser should clearly and conspicuously disclose either the payment or promise of compensation prior to and in exchange for the endorsement.”).

87. See id. § 255.5 exs. 1-9.

88. See id. § 255.5 exs. 6-7.

89. See Recent Regulation, FTC Extends Endorsement and Testimonial Guides to Cover Bloggers-74 Fed. Reg. 53,124 (Oct 15. 2009) (to be codified at 16 C.F.R. pt. 255), 123 HARV. L. REV. 1540, 1545 (2010) (citing Procter \& Gamble Co. v. Amway Corp., 242 F.3d 539 (5th Cir. 2001); Bracco Diagnostics, Inc. v. Amersham Health, Inc., 627 F. Supp. 2d 384 (D.N.J. 2009); Oxycal Labs., Inc. v. Jeffers, 909 F. Supp. 719 (S.D. Cal. 1995)) [hereinafter Recent Regulation, FTC Extends Guides]. "[C]ourts have not found speech to be commercial where the speaker's economic motivation is significantly less direct." $I d$.

90. SEC v. Wall Street Publ'g Inst., Inc., 851 F.2d 365, 366-67, 371-72 (D.C. Cir. 1988). 
were not commercial speech because there was no economic motivation behind them. ${ }^{91}$ Another example where a court found economic motivation insufficient to support a finding of commercial speech involved research published in a peer-reviewed journal that was sponsored by a manufacturer of the researched product. ${ }^{92}$ The published material was not commercial speech because the manufacturer was not the author of the article, the author was not paid by the manufacturer, the publication "did not advocate that the reader purchase a particular product over another," and the research was published by an impartial journal. ${ }^{93}$ Based on these examples, a consumer-endorser's receipt of free product samples, alone, should be insufficient to establish economic motivation and classify the speech as commercial.

Consider example eight of $\S 255.0$ of the Guides. ${ }^{94}$ According to the Guides, a material connection exists if such a connection "might materially affect the weight and credibility of the endorsement" or "is not reasonably expected by the audience." "55 Under example eight of § 255.0, a consumer who blogs about purchasing a new brand of dog food is not an endorser. ${ }^{96}$ If she received a coupon for a free trial of the dog food, then she still would not be an endorser. ${ }^{97}$ If, however, she received the product through a network-marketing program where she periodically receives various products from a variety of advertisers about which she can choose to write reviews, then she would be an endorser. ${ }^{98}$

It is unclear why receiving a free product from a coupon does notand the marketing program does-materially affect the weight and credibility of the endorsement. ${ }^{99}$ The consumer is under no pressure to submit a positive review in either scenario. Further, receipt of the product from a network-marketing company, rather than the manufacturer itself, distances the blogger and the advertiser. Finally, choosing to submit a review establishes that the consumer is not under the control of the advertiser. These three factors considered as a whole

91. Id. at 372 .

92. Braco Diagnostics, 627 F. Supp. 2d at 407, 457.

93. Id. at 457.

94. 16 C.F.R. § 255.0 ex. 8 (2011).

95. Id. § 255.5 .

96. Id. § 255.0 ex. 8.

97. Id.

98. Id.

99. See Public Comment from David Balter, Chief Exec. Officer, BZZAgent, Inc., to Fed. Trade Comm'n 4-5, 7 (Feb. 26, 2009) available at http://www.ftc.gov/os/comments/endorsement guide52/539124-00004.pdf (distinguishing between consumer-endorsers and actual consumers). 
establish that receipt of the free product does not affect the weight and credibility of the endorsement. In addition, these facts decrease the likelihood of the existence of an economic motivation behind such a user-generated message. If manufacturer-sponsored research does not establish economic motivation, then positive consumer statements about free dog food received from a third party that is not associated with the manufacturer also should not establish economic motivation.

\section{b. Economic Motivation Versus Economic Value}

The mere receipt of a free product does not, in itself, prove an economic motivation for the endorsements that follow. Courts applying the Bolger analysis for commercial speech look to the motivation, not just the economic value behind the speech. ${ }^{100}$ In applying the Bolger analysis, the Third Circuit noted that "[t]here may be cases in which the character of the speech is unclear and in which testimony concerning the motivation of the listeners and the educational or social value of the speech might be relevant in determining whether the speech is commercial or pure for [F]irst [A]mendment purposes."101 The Third Circuit also found that in such instances an inquiry into the motivation of the speaker as well as the audience "would no doubt be relevant."102 The FTC could benefit from recognizing a distinction between economic value and economic motivation.

Businesses provide free products as a cost-effective method to generate more reviews and feedback-good or bad. ${ }^{103}$ Unless the blogger bases the content of the review on the receipt of the free product, the speech is not "fundamentally premised on a direct economic relationship between the company and the promoter."104 Thus, the FTC cannot automatically infer economic motivation based on every receipt

100. See, e.g., Am. Future Sys., Inc. v. Pa. State Univ., 752 F.2d 854, 861-63 (3d Cir. 1984) (citing Bolger v. Youngs Drug Prods. Corp., 463 U.S. 60, 67 (1983)); Nat'l Life Ins. Co. v. Phillips Publ'g, Inc., 793 F. Supp. 627, 645 (D. Md. 1992) ("Economic motivation ... is not enough to turn ... statements into commercial speech.” (citing Bolger, 463 U.S. at 67)).

101. Am. Future Sys., 752 F.2d at 862.

102. Id. at 862 n.26.

103. See Glynn Public Comment, supra note 65, at 6 ("Product and service reviews benefit consumers, and expert critics would not be able to review as many products and services as they do if they had to pay for them. Thus, businesses have customarily provided complimentary products and services to critics ....”).

104. Recent Regulation, FTC Extends Guides, supra note 89, at 1545 (quoting United States v. Wenger, 427 F.3d 840, 848 (10th Cir. 2005)) (internal quotation marks omitted). 
of a free product. Often, receipt of the free sample may not have been the consumer's first encounter with that product. "The Guides require disclosure of the mere fact that the product was provided for free, whether or not an endorsement was written in exchange for free products." ${ }^{105}$ Rather than evaluating the mere value of the products, the FTC should base the determination on the economic motivation of the speaker to review the product, which would allow the FTC to limit its regulation to only commercial speech.

The Guides regulate any message that includes a material connection to an advertiser or product manufacturer; ${ }^{106}$ thus, any message with a material connection must be commercial speech. The definition of material connection, however, does not always establish a sufficient economic motivation behind the message and, therefore, regulates more than commercial speech.

\section{Commercial Speech in New Media}

The disparity in treatment of traditional media and new media creates further ambiguity in determining whether a material connection or an economic motivation exists in user-generated speech. The major marketing and advertising associations admit that "it is a longstanding and common practice among marketers to provide free products or services ... to ... professional critics who, in turn, give reviews of the products." 107 The FTC does not require reviewers in traditional media to disclose such connections. ${ }^{108}$ After the release of the revised Guides, the FTC attempted to clarify this disparity with a posting on its website:

For a review in a newspaper, on TV, or on a website with similar content, [it is] usually clear to the audience that the reviewer [did not] buy the product being reviewed. [It is] the reviewer's job to write his or her opinion and no one thinks they bought the product-for example, a book or movie ticket-themselves. But on a personal blog, a social networking page, or in similar media, the reader may not expect the reviewer to have a relationship with the company whose

105. Id. at 1546.

106. Id. at 1540 (citing Guides Concerning the Use of Endorsements and Testimonials in Advertising, 74 Fed. Reg. 53,124 (Oct. 15, 2009) (to be codified at 16 C.F.R. pt. 255)).

107. Glynn Public Comment, supra note 65, at 6.

108. Id. 
products are mentioned. Disclosure of that relationship helps readers decide how much weight to give the review. ${ }^{109}$

This clarification only begs the question: Why the difference in treatment? To comport with commercial-speech jurisprudence, the consideration should focus on the economic motivation of the speaker, rather than the media disseminating the message. Commonly, a blogger writes her opinion online just as a product reviewer might in traditional media. ${ }^{110}$ Many companies and marketers use Twitter to serve the same purpose that a traditional news reporter fulfilled in the past. ${ }^{111}$ If the FTC carefully compiled definitions and examples to dispel the vagueness of the distinction between commercial and noncommercial speech in consumer expressions, then it would not need to differentiate between media.

\section{Regulating Commercial Speech Based on Economic Motivation}

The Guides rightfully regulate some instances of commercial speech in user-generated new media. The First Amendment extends only commercial-speech protections to a blogger whose speech is economically motivated by cash or other direct payment; ${ }^{112}$ thus, the FTC may rightfully regulate the blogger engaging in such clear commercial speech. ${ }^{113}$ The differential treatment for actual payment comes because the economic motivation is clear when an advertising agency or product manufacturer pays cash to an endorser. ${ }^{114}$ No 3.

109. The FTC's ReVised Endorsement Guides: What People Are Asking, supra note 35, at

110. But see Jeff Bercovici, Why the FTC's Truth in Blogging Guidelines Are Truly Terrible, DAILYFINANCE (Oct. 6, 2009, 3:15 PM), http://www.dailyfinance.com/2009/10/06/why-the-ftcstruth-in-blogging-guidelines-are-truly-terrible/ ("The FTC guidelines use the terms 'blogs' and 'consumer-generated media' interchangeably, but they're far from synonymous.”).

111. See Heather Lalley, Tweet for Hire: More Big Businesses Hire Professional Tweeters, Associated PRESS, Sept. 2, 2009, available at http://www.msnbc.msn.com/id/32661618/ns/ business-careers/t/more-big-businesses-hire-professional-tweeters/ (describing the increased use of social media, such as Twitter, to advertise companies and their products).

112. Recent Regulation, FTC Extends Guides, supra note 89, at 1543 ("Commercial speech is speech that 'propose[s] a commercial transaction.'” (quoting Bd. of Trs. of the State Univ. of N.Y. v. Fox, 492 U.S. 469, 473-74 (1989))).

113. See id. at 1543-44 (stating that the government regulates commercial speech and bloggers employed by product manufacturers who partake in commercial speech when blogging favorably about manufacturers' products).

114. See id. (citing as an example of commercial speech an instance where a manufacturer paid a blogger who blogged favorably about a manufacturer's product and citing as an example of noncommercial speech an instance where a blogger endorsed a product without receiving payment). 
advertiser would pay a consumer without the expectation that the consumer would in turn endorse the product. Most often, advertisers provide monetary payments pursuant to such an agreement. ${ }^{115}$ Advertisers, however, commonly distribute product coupons or samples to gain product awareness or trial. ${ }^{116}$ These alternative purposes make it difficult to distinguish between commercial endorsements and noncommercial consumer speech based on the receipt of free samples alone. $^{117}$

The vague definitions and the inadequate application of the economic-motivation principle cause the Guides to regulate both commercial and noncommercial speech. The Guides regulate noncommercial speech because the economic motivation behind the speech contained in some of the Guides' examples is insufficient to establish the commercial-speech designation. ${ }^{118}$

\section{B. The Guides' Regulations Are Overbroad and Create a Chilling Effect on Protected Speech}

The Guides' application of FTCA liability to unpaid bloggers or consumer-endorsers is overbroad and creates a chilling effect on protected speech. The overbreadth doctrine enforces the protection of free speech guaranteed by the First Amendment. ${ }^{119}$ The Supreme Court recognizes that "[t]he overbreadth doctrine prohibits the Government from banning unprotected speech if a substantial amount of protected speech is prohibited or chilled in the process."120 An overbreadth challenge poses a facial attack to the regulation's validity by claiming that it infringes protected speech even if other constitutional applications exist. ${ }^{121}$ While the overbreadth doctrine does not protect all speech, the

115. See Laura Sydell, FTC: Bloggers Must Disclose Paid Endorsements, NPR (Oct. 6, 2009), http://www.npr.org/templates/story/story.php?storyId=113548758 (explaining that many advertisers commonly pay bloggers for their endorsements).

116. Recent Regulation, FTC Extends Guides, supra note 89, at 1546 (distinguishing the "quid pro quo between [an] endorser and [an] advertiser” and mere receipt of a free product).

117. See The FTC's Revised Endorsement Guides: What PeOPle ARE AsKing, supra note 35 , at 3 (describing different disclosure requirements for individuals receiving a few free samples from those receiving many free samples).

118. See, e.g., 16 C.F.R. $\S 255.5$ ex. 8 (2011) (citing an instance where disclosure is required but economic motivation is unclear because no money or free products were exchanged between the manufacturer and a person who posts comments on an online message board).

119. Ashcroft v. Free Speech Coal., 535 U.S. 234, 255 (2002).

120. Id.

121. Bd. of Trs. of the State Univ. of N.Y. v. Fox, 492 U.S. 469, 482 (1989) (citing Ohralik v. 
Guides are subject to the doctrine's authority because they include examples of noncommercial consumer speech. ${ }^{122}$ Moreover, policies to prevent a chilling effect on commercial speech support the overbreadth doctrine's application to the Guides. This section will explain why the Guides' requirement that material connections must be disclosed by consumers when speaking online is overbroad and needs refinement to avoid a chilling effect on legitimate speech.

\section{Establishing Overbreadth}

In general, the overbreadth doctrine typically does not apply to commercial speech because it is a "hardy breed of expression" less susceptible to the chilling effect. ${ }^{123}$ Thus, any challenge to the constitutionality of a regulation must demonstrate that the speech is protected under the First Amendment. ${ }^{124}$ As discussed above, a blogger's unpaid endorsement of a product is not likely to be commercial speech unless sufficient economic motivation influences the content. ${ }^{125}$ Application of the Guides to online sources, therefore, regulates a substantial amount of protected, noncommercial consumer speech.

The Guides are overbroad based on their regulation of commercial and noncommercial speech alike. A statute is overbroad if it prohibits constitutionally protected activity. ${ }^{126}$ The Guides' regulation of bloggers who receive cash and other direct economic benefits is a permissible regulation of commercial speech. ${ }^{127}$ Their application to noncommercial

Ohio State Bar Ass'n, 436 U.S. 447, 462 (1978)).

122. The Guides use examples to illustrate the FTC's views on disclosure of material connections. See 16 C.F.R. § 255.5 exs. 1-9. In several examples, bloggers and other online reviewers must disclose a material connection after receiving a single item of nominal value from a manufacturer or even a third-party network-marketing program. Id. § 255.5 exs. 7-9. These examples illustrate regulation of noncommercial speech because the economic motivation behind the speech is insufficient to establish a commercial-speech designation. See supra Part III.A.

123. Cent. Hudson Gas \& Elec. Corp. v. Pub. Serv. Comm'n, 447 U.S. 557, 564 n.6 (1980) (citing Bates v. State Bd. of Ariz., 433 U.S. 350, 381 (1977)). "Unconstitutional restriction of expression ... is less likely where the expression is linked to 'commercial well-being' and therefore is not easily deterred by 'overbroad regulation.'” Id. at n.8 (citing Bates, 433 U.S. at 381).

124. See id. 464-66 (providing examples of permitted regulation under the First Amendment).

125. See supra Part III.A.

126. Grayned v. City of Rockford, 408 U.S. 104, 114 (1972) (citing Zwickler v. Koota, 389 U.S. 241, 249-50 (1907)).

127. See Recent Regulation, FTC Extends Guides, supra note 89, at 1544 (“[C]ourts have generally determined speech to be commercial only where a sufficiently direct economic motivation exists - that is, where the speaker's main goal is either to sell his own products or to get paid by the product's manufacturer.”); see also supra Part III.A. 
speech-such as bloggers who receive free samples and whose speech does not create sufficient economic motivation-is impermissible and unconstitutional. ${ }^{128}$ Such unconstitutional regulation of both commercial and noncommercial speech creates ambiguities that chill a consumer's legitimate sharing of product reviews.

As eloquently stated by the Supreme Court, "The Constitution gives significant protection from overbroad laws that chill speech within the First Amendment's vast and privileged sphere.” 129 A court will only invalidate a statute based on overbreadth if it inhibits a substantial amount of protected speech. ${ }^{130}$ Proving that a law chills a substantial amount of protected speech invalidates all enforcement of the law "until and unless a limiting construction or partial invalidation so narrows" the reach of the regulation to remove the threat of a chilling effect. ${ }^{131}$

Courts must apply a limiting construction of a statute when analyzing the statute's overbreadth in order to eliminate the statute's overreach and maintain its legislative purpose. ${ }^{132}$ If possible, courts may also sever the overbroad portion of the statute. ${ }^{133}$ Likewise, a court may sever an overbroad portion of the Guides.

The Guides have the possibility of inhibiting product reviews by independent consumers who do not purchase a product because they are unsure if a material connection exists. Such an inhibition affects a significant amount of important consumer speech and limits the marketplace of ideas. If the Guides only applied to paid bloggers, and the FTC either severed the portion that applies to endorsers receiving free sample products or further defined the receipt of free products in terms of economic motivation, then the Guides could avoid invalidation for overbreadth.

\section{Distinguishing Commercial and Noncommercial Speech}

In Maldonado v. Morales, the plaintiff, Maldonado, challenged the constitutionality of billboard regulations and raised arguments

\footnotetext{
128. See supra Part III.A.

129. Ashcroft v. Free Speech Coal., 535 U.S. 234, 244 (2002).

130. New York v. Ferber, 458 U.S. 747, 771 (1982).

131. Virginia v. Hicks, 539 U.S. 113, 118-19 (2003) (quoting Broadrick v. Oklahoma, 413 U.S. 601, 613 (1973)) (internal quotation marks omitted).

132. Broadrick, 413 U.S. at 611-13.

133. Id. at 613 .
} 
concerning the Guides. ${ }^{134}$ The defendant, the California Department of Transportation, regulated billboard placement by differentiating between billboards that conveyed commercial and noncommercial messages. ${ }^{135}$ The plaintiff argued the distinction was "vague and therefore fail[ed] to give sufficient notice of the prohibited conduct and chill[ed] protected speech."136 The plaintiff alleged that the vagueness of the distinction caused regulation of noncommercial speech, and thus, the statute was overbroad. ${ }^{137}$ The Ninth Circuit found that "[t]he standard for unconstitutional vagueness is whether the statute 'provide[s] a person of ordinary intelligence fair notice of what is prohibited, or is so standardless that it authorizes or encourages seriously discriminatory enforcement.",138 Although the court held the statute was neither unconstitutionally vague nor overbroad because the statute recognized the distinction between commercial and noncommercial speech, ${ }^{139}$ the plaintiff's arguments have a more successful application to the Guides.

Emerging issues regarding user-generated commercial speech distinguish the reasoning that invalidated Maldonado's claim for vagueness and overbreadth from the reasoning that applies to the Guides. In Maldonado, the court held that a statute or regulation is not unconstitutionally vague or overbroad merely because a distinction exists between commercial and noncommercial speech. ${ }^{140}$ Similarly, the Ninth Circuit in Outdoor Systems, Inc. v. City of Mesa reasoned that because "First Amendment jurisprudence recognizes a distinction between commercial and noncommercial speech, government officials have to place a particular message into one or the other category for purposes of regulation."141 There is little jurisprudence, however, addressing the distinction between commercial and noncommercial speech in usergenerated media.

The fact that consumers now produce both commercial and noncommercial messages necessitates a broadening of the definitions of commercial and noncommercial speech. It is no longer an issue of

134. 556 F.3d 1037, 1045 (9th Cir. 2009), cert. denied sub nom., Maldonado v. Iwaski, 130 S. Ct. 1139 (2010).

135. Id. at 1041.

136. Id. at 1045.

137. Id.

138. Id. (second alteration in original) (quoting United States v. Williams, 553 U.S. 285, 304 (2008)).

139. Id. at $1045-46$.

140. Id.

141. 997 F.2d 604, 613 (9th Cir. 1993). 
"plac[ing] a particular message into one category or the other category." 142 The FTC must broaden and redefine categories to avoid vague and arbitrary guidelines dividing commercial and noncommercial speech in user-generated media. The issues that arise in categorizing consumer speech as commercial or noncommercial under the Guides are significant enough to distinguish an overbreadth challenge to the Guides from the overbreadth challenge in Maldonado. The Guides' definition of "material connection" fails to distinguish between commercial and noncommercial speech by ignoring the economic motivation of the speaker. ${ }^{143}$ This failure causes the FTC to regulate both commercial and noncommercial speech under current First Amendment caselaw. An additional factor affecting the Guides exists, however, because courts have not yet recognized an applicable distinction between commercial and noncommercial speech in user-generated media.

In another relevant case, the Ninth Circuit found that a city ordinance prohibiting off-premises canvassing on the Las Vegas strip suffered from overbreadth because it prohibited not only commercial speech, but also fully protected speech that was "inextricably intertwined" with commercial speech. ${ }^{144}$ The Supreme Court recognizes that even after assuming speech is commercial, such "speech [does not] retain[] its commercial character when it is inextricably intertwined with otherwise fully protected speech." ${ }^{\text {,45 }}$ The ordinance did not limit its restrictions to purely commercial speech. ${ }^{146}$ The Ninth Circuit found that "[a]bsent such a limitation, there [was] a substantial likelihood that the [ordinance] inhibit[ed] the expression of fully protected speech intertwined with commercial speech."147 The vagueness of the Guides creates a similar effect-intertwining commercial speech and noncommercial speech by regulating the speech based primarily on medium rather than economic motivation.

With the wide reach of the FTC's interpretations, ${ }^{148}$ there is an obvious need for clear, unambiguous Guides to avoid a widespread

\footnotetext{
142. Id.

143. See 16 C.F.R. § 255.5 (2011) (defining a material connection for purposes of the Guides).

144. S.O.C., Inc. v. Cnty. of Clark, 152 F.3d 1136, 1140, 1143-44 (9th Cir.), amended by 160 F.3d 541 (9th Cir. 1998).

145. Riley v. Nat'l Fed'n of the Blind of N.C., Inc., 487 U.S. 781, 796 (1988).

146. S.O.C., $152 \mathrm{~F} .3 \mathrm{~d}$ at 1143 ("[T] 14 Ordinance’s plain language does not limit the scope of the regulated activity to purely commercial expression.”).

147. Id. at 1144.

148. See supra notes $47-51$ and accompanying text.
} 
chilling effect on legitimate speech. While the Guides provide examples for distinguishing between a free product that warrants a material connection and a free product that does not, there is no discernable test to determine whether a customer has a material connection to an advertiser or manufacturer. If consumers are aware of the regulations, but cannot discern whether their opinion constitutes an endorsement, they may refrain from sharing their views altogether. For example, a consumer may have already formed an opinion of the product prior to receiving the free sample. Thus, the consumer's opinion is not economically motivated and, therefore, not commercial speech. Such a consumer, however, is subject to the current Guides' regulation and could incur liability for any misleading or false advertising pursuant to the recently adopted joint-liability section of the revised Guides. This exemplifies the chilling effect the Guides could have on noncommercial, consumer product endorsements_-free speech.

\section{Little Downside Exists to Refining the Guides}

Although many commentators have analyzed the overreaching of the revised Guides, ${ }^{149}$ a few proponents support the existing Guides. ${ }^{150}$ At least one commentator has called for more stringent regulation by the FTC. ${ }^{151}$ While these proponents have valid arguments for the sufficiency of the current Guides, further revision of the Guides to prevent a chilling effect does not hinder any such arguments.

Proponents of the current disclosure guidelines argue that failure to regulate disclosure will result in "deterioration in the credibility of public discourse, because audiences [will not] be able to trust that a stated opinion is independent and sincerely held." ${ }^{152}$ These proponents argue

149. See supra Part III.A-B (describing the Guides as overbroad).

150. See Michael J. Patterson, Student Article, Experts, Celebrities and Bloggers Beware: The FTC Publishes Revised Guides Concerning the Use of Endorsements and Testimonials in Advertising, 22 LOY. CONSUMER L. REV. 497, 511-12 (2010) (opining that the Guides are necessary); see also Robert J. Ambrogi, The FTC Blog Rules: Overbroad or Overblown?, LEGAL BLOG WATCH (Oct. 7, 2009, 12:52 PM), http://legalblogwatch.typepad.com/legal_blog_watch/2009/ 10/the-ftc-blog-rules-overbroad-or-overblown.html (asserting that reactions to the Guides exaggerate their scope).

151. Public Comment from Monyei-Hinson, to Fed. Trade Comm'n (Feb. 13, 2009), available at, http://www.ftc.gov/os/comments/endorsementguides2/539124-00003.pdf.

152. Rebecca Tushnet, Attention Must Be Paid: Commercial Speech, User-Generated Ads, and the Challenge of Regulation, 58 BufF. L. REv. 721, 751 (2010) (citing George A. Akerlof, The Market for Lemons: Quality Uncertainty and the Market Mechanism, in EXPLORATIONS IN Pragmatic Economics: Selected Papers of George A. AKerlof (AND CO-Authors) 27, 33- 
that the reaction to the Guides' regulation is overblown because the FTC intends for the Guides to regulate marketing practices that "exploit viral media by paying for favorable reviews - whether the payment is in cash or goods."153 They claim that the disclosure required is not "onerous," and "[a]ll a blogger needs to do is to add a line to the particular post saying what was received, whether it was a payment, a free sample[,] or something else of value."154

Several arguments rebut the claim that the Guides cause a deterioration of public discourse. First, commentators calling for further revision do not seek elimination of the disclosure for any material connections. Rather, further revision will serve both sides' interests by continuing to regulate those "exploit[ing] viral media"155 while lessening the chilling effect on legitimate consumer opinions. By encouraging legitimate consumer opinions, user-generated media will be less polluted with advertisers abusing its unique attributes. Second, overuse of disclosure may negatively impact the credibility of a blogger. In addition, according to an article analyzing the impact of the requirements on the blogging world, "at least one blogger is already raising concerns that angry readers may use the regulations to attempt to get back at blogs they [do not] like."156 Consumers are wary of commercial messages, and the disclosure of an endorser's receipt of free products by trusted consumer sources could undermine the reputation of a blogger. Online peer reviews are the most trusted form of advertising, ${ }^{157}$ and an overabundance of unnecessary disclosures could lead consumers away from the belief that the blogger speaks independently and out of a genuine experience with the product. Thus, requiring disclosures only when actually necessary serves the best interest of the uninhibited marketplace of ideas.

\footnotetext{
34 (2005)).

153. Ambrogi, supra note 150.

154. Id.

155. Id.

156. Caroline McCarthy, Yes, New FTC Guidelines Extend to Facebook Fan Pages, CNET News (Oct. 5, 2009), http://news.cnet.com/8301-13577_3-10368064-36.htm.

157. Press Release, Nielsen Co., Personal Recommendations and Consumer Opinions Posted Online Are the Most Trusted Form of Advertising Globally (July 7, 2009), http://blog.nielsen.com/ nielsenwire/wp-content/uploads/2009/07/pr_global-study_07709.pdf ("Ninety percent [of] consumers surveyed noted that they trust recommendations from people they know, while [seventy] percent trusted consumer opinions posted online.”).
} 
While many argue that disclosing material connections is a safe strategy, ${ }^{158}$ the imposition of this requirement infringes on constitutionally protected freedom. Furthermore, "if the governmental interest could be served . . . by a more limited restriction on commercial speech, [then] the excessive restrictions cannot survive."159 Even conceding that protecting consumers from false advertising is a substantial government interest, the regulation must be narrowly tailored to that interest. ${ }^{160}$ The FTC could further revise the definitions and examples to more narrowly tailor the Guides. ${ }^{161}$

\section{Congressional and Judicial Policies Support Further Revision of the Guides}

Policies behind the overbreadth doctrine as well as other recognized congressional policies support the invalidation of the Guides. An examination of the policy reasoning behind similar regulations supports refining the Guides for reasons other than the chilling effect it creates on legitimate speech. Currently, the Guides conflict with long-supported policies regarding communications media.

Courts see the threat of the chilling effect as so important that they alter the "traditional rules of standing" to allow claims of overbreadth. ${ }^{162}$ The Supreme Court recognizes that "[l]itigants... are permitted to challenge a statute not because their own rights of free expression are violated, but because of a judicial prediction or assumption that the statute's very existence may cause others not before the court to refrain from constitutionally protected speech or expression.”" 63 The overbreadth doctrine is predicated on the notion that the chilling effect harms society by depriving it of an "uninhibited marketplace of ideas."164 Thus, the FTC must refine the Guides not only because it is unconstitutional to chill legitimate free speech, but also because the Guides must maintain the free and uninhibited marketplace of ideas.

\footnotetext{
158. Ambrogi, supra note 150.

159. Cent. Hudson Gas \& Elec. Corp. v. Pub. Serv. Comm’n, 447 U.S. 557, 564 (1980).

160. See id. ("The limitation on expression must be designed carefully to achieve the State's goals.").

161. See discussion supra Part III.B and infra Part III.D.

162. Broadrick v. Oklahoma, 413 U.S. 601, 612 (1973) (citing Dombrowski v. Pfister, 380 U.S. 479, 486 (1965)).

163. Id.

164. Virginia v. Hicks, 539 U.S. 113, 119 (2003).
} 


\section{Policies Relating to Regulating Internet Communication}

Policies announced in other laws governing the regulation of communication on the Internet also support further revisions of the Guides. Congress has recognized that fostering Internet speech constitutes an important policy, which it promotes through legislation. ${ }^{165}$ The current version of the Communications Decency Act, ${ }^{166}$ which reduces the liability of interactive service providers under certain circumstances, "was enacted, in part, to maintain the robust nature of Internet communication and, accordingly, to keep government

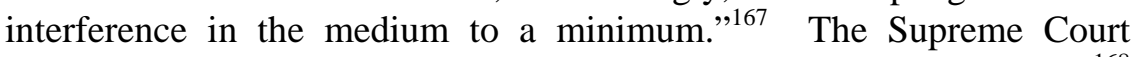
severed some original portions of the Act for being facially overbroad. ${ }^{168}$ One commentator applauded the Court for recognizing the "tremendous potential the Internet offers for speech" and also understanding that usergenerated content increases "people's education and ability to interact in a global marketplace.”169

In enacting the Communications Decency Act, Congress determined that the United States supports a policy of "promoting the continued development of the Internet" and "encourag[ing] the development of technologies which maximize user control over what information" the user receives when using the Internet. ${ }^{170}$ Congress also published specific findings regarding its views on Internet speech and related policies:

(1) The rapidly developing array of Internet and other interactive computer services available to individual Americans represent an extraordinary advance in the availability of educational and informational resources to our citizens[;]

(2) These services offer users a great degree of control over the information that they receive, as well as the potential for even greater control in the future as technology develops[;]

(3) The Internet and other interactive computer services offer a forum for a true diversity of political discourse, unique opportunities for

\footnotetext{
165. See 47 U.S.C. § 230 (2006) (containing congressional findings that speak favorably about the Internet).

166. Id.

167. Zeran v. Am. Online, Inc., 129 F.3d 327, 330 (4th Cir. 1997).

168. Reno v. ACLU, 521 U.S. 844, 882-83 (1997).

169. Lee, supra note 8, at 1504-05.

170. 47 U.S.C. § 230(b)(1), (3).
} 
cultural development, and myriad avenues for intellectual activity[;]

(4) The Internet and other interactive computer services have flourished, to the benefit of all Americans, with a minimum of government regulation[; and]

(5) Increasingly[,] Americans are relying on interactive media for a variety of political, educational, cultural, and entertainment services. ${ }^{171}$

These findings mirror the policy behind the overbreadth doctrineexpanding the marketplace of ideas and keeping it free and uninhibited. ${ }^{172}$ Although these policies and findings do not conflict with the FTC's authority to regulate false advertising, they do necessitate the use of narrowly tailored regulations. ${ }^{173}$ The Guides are currently vague and too broad to comport with congressional policies regarding usergenerated content on the Internet. The current Guides' chilling effect on legitimate consumer speech is in direct opposition to the policies of maximizing user control and minimizing government interference in Internet speech.

2. Policies Relating to Regulating Traditional Forms of Communication

In addition to current congressional and judicial policies regarding the Internet, policies that guide regulation of "old" media suggest the Guides need further consideration. In Denver Area Educational Telecommunications Consortium, Inc. v. FCC, the Court considered the development of standards for applying free speech regulations to the "new" media of cable television. ${ }^{174}$ In a plurality opinion, three Supreme Court Justices recognized the importance of avoiding undue haste in determining standards for new communications technologies. ${ }^{175}$ "Justice Breyer was reluctant to formulate a rule that would be binding on cable television while the evolution of cable television as a medium of

171. Id. § 230(a)(1)-(5).

172. See Broadrick v. Oklahoma, 413 U.S. 601, 611-12 (1973) ("It has long been recognized that the First Amendment needs breathing space and that statutes attempting to restrict or burden the exercise of First Amendment rights must be narrowly drawn ....”).

173. See id.

174. 518 U.S. 727, 742 (1996) (plurality opinion).

175. Id. 
communication remained in great flux." ${ }^{\text {176 }}$ Breyer's idea is reflected in many of the comments made to the proposed Guides. At least two communications-industry commenters believed the FTC should take time to gather information about the growing area of user-generated content before stepping in with regulations. ${ }^{177}$ The issues facing the regulation of cable television illustrate the need for thoughtful regulation of developing communications media in accordance with long-recognized policies governing the regulation of communications media.

The concurring opinion authored by Justice Souter, who joined Justice Breyer's plurality, echoed the policy now recognized in the Communications Decency Act ${ }^{178}$ of "maintaining the high value of open communication" in new media. ${ }^{179}$ The Justices, however, recognized open communication in cable television rather than on the Internet. ${ }^{180} \mathrm{By}$ regulating both commercial and noncommercial speech alike, the Guides fail to maintain this high value of open communication. Therefore, policies should support the need and importance of adopting narrowly tailored definitions and examples in the Guides to maintain open communication and limit the chilling effect on legitimate speech.

The Supreme Court judged the intrusiveness of regulations for cable television "in terms of editorial control and the large... number of channels open for communication."181 Based on this policy, the adaptation and application of twenty-year-old Guides to a "unique and wholly new medium of worldwide human communication"182 is inappropriate. The Guides do not consider all of the unique attributes of user-generated content as evidenced by the lack of sufficient definitions.

The chilling effect that occurs because of the overbroad Guides is not only void under the Constitution, but also directly conflicts with

176. Kline, supra note 1 , at 33.

177. See Public Comment from Richard F. O’Brien, Exec. Vice-President of the Am. Ass'n of Adver. Agencies, and Jeffrey L. Perlman, Exec. Vice-President of the Am. Adver. Fed'n, to Fed. Trade Comm'n 17-18 (Mar. 2, 2009), available at http://www.ftc.gov/os/comments/ endorsementguides2/539124-00008.pdf [hereinafter O’Brien \& Perlman Public Comment] (“Given the exponential speed with which new media, including blogs, are developing and changing, it is premature for the Commission to institute specific regulations in this area.").

178. See generally 47 U.S.C. § 230 (2006) (describing the Internet as a useful tool that should be promoted).

179. Denver Area Educ. Telecomms. Consortium, 518 U.S. at 778 (Souter, J., concurring).

180. See id. at 732 (plurality opinion) (identifying the First Amendment's challenge to regulation of material on cable television).

181. Kline, supra note 1, at 28 (citing ACLU v. Reno, 929 F. Supp. 874, 877 (E.D. Pa. 1996) (Dalzell, J., concurring), aff'd, 521 U.S. 844 (1997)).

182. Id. at 43 (quoting $A C L U$, $929 \mathrm{~F}$. Supp. at 844) (internal quotation marks omitted)). 
congressional policies. By adhering to the policies from prior communications regulations, the Guides can limit the chilling effect on legitimate consumer-generated speech.

\section{E. The FTC Must Refine the Guides to Avoid Chilling Legitimate Speech}

To avoid chilling legitimate speech, the FTC must revise the Guides to eliminate their application to noncommercial consumer speech. The FTC's failure to frame the Guides in terms of economic motivation causes the FTC to regulate both commercial and noncommercial speech under current First Amendment caselaw. Additionally, current caselaw has not yet recognized an applicable distinction between commercial and noncommercial speech in user-generated media. "With each innovation in communication technology, the Court has been forced to adjust its First Amendment jurisprudence to account for the special attributes of that medium." "183 The FTC should revise the Guides in a way that clarifies ambiguities and carves a path for user-generated media in First Amendment jurisprudence.

Many who commented on the proposed Guides released in 2008 discussed the chilling effect. ${ }^{184}$ Some commenters suggested the FTC refrain from regulating user-generated media until the media was more developed. ${ }^{185}$ The area of user-generated media is fast-growing and may soon require a complete overhaul of not only the Guides regulating consumer and endorsement advertising, but also commercial-speech law as a whole. Thus, prudence suggests that Congress or the FTC should reconsider the comments and suggestions made prior to finalizing the Guides and begin redefining commercial speech as it applies to usergenerated media. The revised Guides constitute a starting point from which further definition of user-generated commercial speech may arise. The examples and definitions provided in the current Guides are insufficient and vague, and the FTC must clearly define them to overcome the constitutional challenge discussed in this Comment. There

183. Id. at 27 (citing ACLU, 929 F. Supp. at 877 (Dazell, J., concurring)).

184. See, e.g., O’Brien \& Perlman Public Comment, supra note 177, at 17-18; Public Comments from Elec. Retailing Ass'n \& Council for Responsible Nutrition, to Fed. Trade Comm'n 28, 31 (Mar. 2, 2009), available at http://www.ftc.gov/os/comments/endorsementguides2/53912400014.pdf.

185. O’Brien \& Perlman Public Comment, supra note 177, at 17-18. 
are many ways that the FTC may refine the Guides to pass a facial constitutional challenge and avoid chilling legitimate speech.

\section{Severing the Invalid Portion}

As stated in Part III.B, the FTC may sever the Guides' application to unpaid bloggers to avoid facial invalidity. After such a revision, the Guides would apply only to paid bloggers. This is not an ideal solution, however, as it would invalidate the application of the statute in instances of commercial speech involving in-kind payments.

\section{Creating an Objective Test for Economic Motivation}

Alternatively, the Guides could also develop an objective test or set of factors to assist in developing a standard under which consumers may evaluate the economic motivation behind an endorsement. Focusing on the economic motivation of the speaker would comply with current First Amendment caselaw ${ }^{186}$ and eliminate overbreadth. Standards should provide notice and fair warning in predicting how courts will "test a law's validity, rather than letting the height of the bar be determined by the apparent exigencies of the day." 187 While controversy exists as to whether economic motivation itself suffices to distinguish between commercial and noncommercial speech when allocating constitutional protection, ${ }^{188}$ such a test would clarify the definition of "material connection." The test would replace the current definition that relies on the value of the product and establish a clear definition for the Guides and eliminate the Guides' current vagueness and overbreadth.

\section{Creating a Categorical Test}

Professor Robert Sprague recently proposed an alternative standard for evaluating commercial speech that could assist in refining the Guides. ${ }^{189}$ He developed the proposed standard after recognizing that

186. See supra Part III.A (discussing the current interpretation of the First Amendment).

187. Denver Area Educ. Telecomms. Consortium, Inc. v. FCC, 518 U.S. 727, 785 (1996) (Kennedy, J., concurring in part and dissenting in part).

188. See Robert Sprague, Business Blogs and Commercial Speech: A New Analytical Framework for the 21st Century, 44 AM. Bus. L.J. 127, 143-48 (2007) (providing a summary of cases discussing the economic motivation factor in the Guides).

189. Id. at $155-56$. 
speech between businesses and consumers is no longer purely commercial because of the constant dialogue between business and consumers. ${ }^{190}$ His proposed standard first determines whether the speech originated from a commercial entity. ${ }^{191}$ After determining that the speech originated from a commercial entity-and is thus commercialhis test examines one of three categories: (1) traditional advertising; (2) public relations; or (3) social commentary. ${ }^{192}$ Speech between businesses and consumers ranges from predominantly fact-based, traditional advertising, to predominately opinion-based, social commentary. ${ }^{193}$ The predominately opinion-based speech receives greater constitutional protection despite its classification as commercial speech. ${ }^{194}$ The traditional-advertising and public-relations categories enjoy less protection because businesses have a higher level of control over such information. ${ }^{195}$ The social-commentary category would be held to an actual malice standard, under which advertisers or endorsers are liable for deceptive advertising that they know is false. ${ }^{196}$

This proposed standard brings out some good ideas that could be refined for application to endorsements as well. Determining whether speech originated from a commercial entity creates a similar problem to determining whether an advertiser and speaker have a relationship that affects the weight and credibility of the endorsement. In applying this formula to consumer-generated speech, one should ignore the original commercial-speech designation and analyze the speech based on the three subcategories. The social-commentary category has helpful application to the regulation of consumer endorsements if the consumer knows that he speaks on behalf of the advertiser but does not disclose the connection then he is liable as an endorser. While the current version of the proposed standard does not resolve the imprecise definition of commercial speech in the Guides, the alternative system of classification and the idea of a sliding scale of protection could further develop into a workable framework for consumer-generated media.

\footnotetext{
190. Id. at 127 .

191. Id. at 155 .

192. Id. at $155-56$.

193. Id. at 156 .

194. Id.

195. Id. at 156-57.

196. Id. at 157.
} 


\section{CONCLUSION}

The application of the Guides to new media blurred the line between consumers and advertisers such that one cannot clearly apply the current Guides Concerning Use of Endorsements and Testimonials in Advertising. The revisions inadequately address the issues facing commercial-speech law in the age of user-generated media, which increasingly takes the place of traditional media. The Guides' application of old endorsement principles to new forms of expression is not enough to remedy the issues arising as consumers begin to infiltrate areas previously occupied by advertisers alone.

Whether the FTC decides to define and differentiate protected consumer endorsement and non-protected commercial endorsement by consumers, it must take action to stop the chilling effect on legitimate speech. The current Guides are vague and regulate noncommercial speech along with commercial speech. Because the revisions provide only vague definitions of "material connection" in consumer endorsements, the Guides are impermissibly broad and encompass both protected and unprotected speech. The regulation of both noncommercial speech and commercial speech creates a chilling effect on legitimate Internet speech and detracts from the open marketplace of ideas. This chilling effect prevents the Guides from passing a facial constitutional challenge of overbreadth.

Moreover, long-standing policies governing both Internet and communication regulation support revisions to the Guides. Federal lawmakers recognize that communication regulation should not inhibit the high value of open communication; rather, regulation should support the uninhibited, free marketplace of ideas. Therefore, the FTC must revise the Guides both to pass a facial challenge and comport with longrecognized congressional and judicial policies.

The FTC could choose to address only the constitutional issue. Regardless, many issues remain concerning commercial speech that the FTC, Congress, and the courts will soon have to address. If the FTC reacts with only the short term in mind, it must limit the applicability of the Guides to only commercial speech by considering direct economic motivations underlying the speech. If the FTC chooses to address longterm issues, it must reconsider previous distinctions between traditional and new media and develop Guides addressing the motivation of the speaker rather than the medium in which it is disseminated. 